\title{
HIGH LEVELS OF C-REACTIVE PROTEIN ARE ASSOCIATED WITH USE OF BIOLOGIC THERAPY IN NON-RADIOGRAPHIC AXIAL SPONDYLOARTHRITIS PATIENTS
}

Nestor Barreto-Neto ${ }^{1, \star}$, Lucas Araújo Brandão ${ }^{1}$, Ana Cristina Medeiros Ribeiro ${ }^{1}$, Julio Cesar Bertacini de Moraes ${ }^{1}$, Claudia Goldenstein Schainberg ${ }^{1}$, Percival Degrava Sampaio-Barros ${ }^{1}$, Celio Roberto Gonçalves ${ }^{1}$, Carla Gonçalves Schahin Saad ${ }^{1}$

1.Universidade de São Paulo, São Paulo (SP), Brazil.

*Corresponding author: nestor.barreto@hc.fm.usp.br

\section{BACKGROUND}

The Assessment of SpondyloArthritis international Society (ASAS) has defined criteria for non-radiographic axial spondyloarthritis (nr-axSpA) in 2009. To date, there are no Brazilian studies that evaluate clinical outcomes of patients with nr-axSpA, especially regarding use of biologic therapy in these patients. The aim of this study is to identify the clinical and laboratory characteristics of $\mathrm{nr}$-axSpA, as well as predictors of use biologic therapy in a tertiary outpatient center in Brazil.

\section{MATERIALS AND METHODS}

All patients classified as nr-axSpA and with diagnosis of axial SpA of a tertiary outpatient center in Brazil were included in a retrospective analysis. Baseline clinical and laboratory data were collected, as well as clinical and disease treatment in follow-up using a longitudinal electronic database.

\section{RESULTS}

Sixty-six patients with nr-axSpA were selected to the study, 41 (62.1\%) males with 75\% of HLA-B27 positive. Mean age of symptoms onset was $29.3 \pm 2.7$ years and the mean time from symptom onset until diagnosis was $4.7 \pm 1.59$ years. Mean duration of follow-up was $7.56 \pm 1.67$ years. Comparing patients who used biological therapy during the follow-up with patients who did not use, higher levels of baseline C-reactive protein was independently associated with introduction of biological therapy [31.5 (0.5-160) vs. 6.7 (0-162) $\mathrm{mg} / \mathrm{L}, \mathrm{p}<0.001)$ ] while the presence of ankle arthritis at baseline was independently associated with no biological therapy during follow-up $(p=0.048)$.

\section{CONCLUSION}

In this retrospective study with a long-term follow-up high levels of $\mathrm{C}$ reactive protein at baseline is associated with biological use in a single center cohort of nr-axSpA. Further prospective studies are necessary to confirm this data and to evaluate the impact of use of biological therapies in these patients. 